\title{
Utilization of Betel Leaf Extract as Botanical Pesticides to Control meloidogyne spp. and Tomato Plant Production
}

\author{
Made Sritamin* and I Dewa Putu Singarsa \\ Agroechotechnology Program, Faculty of Agriculture of Udayana University \\ *Corresponding author: madesritamin@gmail.com
}

\begin{abstract}
Meloidogyne spp. Are among the polyphagous pest that has spread around the world and has been reported to attack cultivated plants with economic values. Various ways had been applied to control the Meloidogyne spp. nematodes but has not yet showed any effective results. We are currently using synthetic pesticides because of its fast response and ability to maintain plant productions. The improper application of synthetic nematicides would have a negative impact on the environment. The aim of this research is to know the effectiveness of betel leaf concentration (Piper betel L.) to curb the development of nematodes on Root-Knot Meloidogyne spp and the growth of tomato plants. This is a descriptive research, with the utilization of betel leaf extract (Piper betel L,) by concentration treatment of 0\%, 5\%, 10\%, $15 \%$ and 20\%, each of which are repeated five times. Complete Random Sampling (CRS) with the F test is used and continued with the Duncan test at a 5 $\%$ rate. The result shows that the betel leaf extract of the $20 \%$ concentration was the most effective either on the growth of plants and to the root-knot nematodes. The suppression of growth in the ground was 80,06\% and the lowest was recorded with the 5\% concentration ( $2,32 \%)$; the suppression of root-knot was $45,45 \%$ while the lowest was with the $5 \%$ concentration $(12,12 \%)$; the suppression of nematodes population in the roots was 45,45 $\%$ while the lowest was with the 5\% concentration (39,76\%); and last was the suppression of egg mass which was $61,73 \%$ while the lowest was shown in the 5\% concentration (18,32\%). It can be concluded in this research that the most effective betel leaf extract concentration was at $20 \%$.
\end{abstract}

Keywords: Meloidogyne spp., Piper betel L., CRS

\section{INTRODUCTION}

There was a decrease in tomato plant productions from 647.020 tons in 2005 to 629.744 tons in 2006 [1]. One of the important pests causing the decrease of tomato production is the root-knot nematodes causing root ulcers, Meloidogyne spp. These nematodes have an important role in causing damage on the roots of horticultural plants, crops, plantation, and weeds [2]. The damage caused by Melodogyne spp. especially in tomato plants around the world is significant. Meloidogyne spp. are among the concerning pests due its polyphagous characteristic and its growth population has spread around the world [3].

The Meloidogyne spp. nematode attacks almost every vegetable plant and some plants can be attacked by more than one nematodes species. Meloidogyne spp. are spread all around the world and many have been reported to attack cultivation plants with economic values, serious losses could occur when plants are severely infested. Agrios (1969) stated that losses due to root-knot nematodes Meloidogyne spp. are variable depending on the type of plant being infested, the species of Meloidogyne, and the environment condition [4]. If young susceptible plants are infested, it would cause it to die, however if an adult plant are infested, it would have only a small effect towards the production.

From previous studies using many plant leaves extract as botanical pesticides, it is found that the use of betel leaf extract was the best way to suppress nematodes population, however it is not yet known the most effective concentration of its botanical use to control nematodes [5]. Meloidogyne spp. nematodes attack almost all vegetable plants and some of those plants can be attacked by more than one nematode species. Meloidogyne spp. are spread all across the world and have been reported to attacked many cultivation plants with economic values, of which severe losses can happen if the plants are severely infested. Agrios (1969) stated that the loss due to root-knot nematodes Meloidogyne spp. varies depending on the types of plants.

Various ways of controlling is applied towards rootknot nematodes Meloidogyne spp. which includes plantation of nematode resistant varieties, plant rotation, and technical culture, however these controlling methods is less effective to suppress Meloidogyne spp. population [6]. Until now, many farmers are still using synthetic pesticide on tomato plantation to control nematodes due 
to its fast response and ability to maintain plant productions; however improper application of synthetic nematicides will have a negative outcome towards the environment. The purpose of this research is to know the effectiveness of the concentration level of betel leaves extract to suppress the development of root-knot nematodes Meloidogyne spp. in tomato plants, to know the development of tomato plants after being treated with betel leaves extract and also to know the result of tomato plant productions. The major purpose in this research is to support farming and to increase their family income, especially for tomato productions.

\section{RESEARCH METHOD}

The research is conducted in an experiment garden of the Agriculture Faculty in conjunction with Laboratory of Pests and Plant Disease of Agriculture Faculty Udayana University, of which is a descriptive research which utilize piper betel leaf extract as treatment with the concentration of $0 \%, 5 \%, 15 \%$ and $20 \%$. Each treatment is done with five repetitions which are given to tomato plants which have been infested with root-knot nematodes, Meloidogyne spp. This research uses a Complete Random Design (CRD) analyzed by F-test and continued with Duncan'N 0,05 (5\%).

\section{RESULTS AND ANALYSIS}

The research result shows that all treatment that was given had a real effect towards all changes that was observed. Towards the growth of plants, the concentration of betel leaf extract that was used, has given different effects on the changes observed, one of which the $20 \%$ concentration has given the best result towards plant growth compared to the other, while the growth is retarded with the usage of lower concentration. This result is supported by other studies conducted by
Ambika and Poonima (2014) in India which states that treatments with Kirinyuh leaf extract applied into the soil of soy bean plantation can increase the height of the plant by $15 \%$, root length by $40 \%$, and attached beans by $163 \%$. Statistical analysis result showed real differences between treatment with $20 \%$ concentration compare with the controls and between treatments which had shown real differences presented in Table 1.

\section{CONCLUSION}

As for the nematodes population in the soil, the $20 \%$ concentration has had the biggest suppression at $80,06 \%$, and the smallest was with the $5 \%$ concentration with $2,32 \%$; as for the amount of root-knot, the $20 \%$ concentration suppression was $45,45 \%$ and lowest was with the $5 \%$ concentration at $12,12 \%$; as for nematodes in the roots, the $20 \%$ concentration suppression was $76,14 \%$ and lowest was with the $5 \%$ concentration at $39,76 \%$; and for the amount of egg mass with the $20 \%$ concentration suppression was $61,73 \%$ and lowest was with the $5 \%$ concentration at $18,32 \%$. In this research, it has been concluded that the most effective concentration of betel leaf extract is $20 \%$. Treatment applied for plant growth showed the best plant growth also occurred with the $20 \%$ concentration treatment while the least growth occurred with the 5\% concentration treatment. From the result it can be concluded that the best concentration of betel leaf extract is with the $30 \%$ concentration.

Feedback:

1. Need to conduct further research in the field with the effective concentration (20\%) with tomato plantation.

2. Needs to conduct further research with other types of plants and different types of nematodes; on different types of plants that are attacked by root-knot nematodes or parasitic nematodes

TABLE 1.

THE INFLUENCE OF BETEL LEAF EXTRACT APPLICATION IN VARIOUS CONCENTRATIONS TOWARDS SOME CHANGES.

\begin{tabular}{|c|c|c|c|c|c|c|c|c|c|}
\hline $\begin{array}{l}\mathrm{N} \\
0\end{array}$ & Treatment & $\begin{array}{c}\text { Plant } \\
\text { Height } \\
\text { (cm) }\end{array}$ & $\begin{array}{l}\text { Root } \\
\text { Length } \\
(\mathrm{cm})\end{array}$ & $\begin{array}{l}\text { Wet-root } \\
\text { Weight } \\
\text { (g) }\end{array}$ & $\begin{array}{l}\text { Amount } \\
\text { of Fruits }\end{array}$ & $\begin{array}{c}\text { Pop. } \\
\text { nem/ } 300 \\
\text { g soil } \\
\text { (each) }\end{array}$ & $\begin{array}{l}\text { Root- } \\
\text { knot/gr } \\
\text { of root. } \\
\text { (each) }\end{array}$ & $\begin{array}{l}\text { Pop.nem } \\
\text { /gr of root } \\
\text { (each) }\end{array}$ & $\begin{array}{l}\text { Amount of } \\
\text { egg mass / } \mathbf{r} \\
\text { root (each) }\end{array}$ \\
\hline 1 & Control & $48,0 \mathrm{a}$ & $24,0 \mathrm{a}$ & $24,0 \mathrm{a}$ & $1,8 \mathrm{a}$ & $120,4 \mathrm{a}$ & $63,8 \mathrm{a}$ & 100,6 a & 62,2 a \\
\hline 2 & P. $5 \%$ & $\begin{array}{c}55,6 \mathrm{~b} \\
(13,66 \%)\end{array}$ & $\begin{array}{c}39,4 \mathrm{~b} \\
(39,08 \%)\end{array}$ & $\begin{array}{c}41,4 \mathrm{~b} \\
(42,02 \%)\end{array}$ & $\begin{array}{c}3,0 \mathrm{~b} \\
(36,0 \%)\end{array}$ & $\begin{array}{l}117,6 \mathrm{a} \\
(2,32 \%)\end{array}$ & $\begin{array}{c}56,0 \mathrm{~b} \\
(12,12 \%)\end{array}$ & $\begin{array}{c}60,8 \mathrm{~b} \\
(39,76 \%)\end{array}$ & $\begin{array}{c}50,8 \mathrm{~b} \\
(18,32 \%)\end{array}$ \\
\hline 3 & P. $10 \%$ & $\begin{array}{c}60,8 \mathrm{c} \\
(21,05 \%)\end{array}$ & $\begin{array}{c}42,4 \mathrm{c} \\
(43,39 \%)\end{array}$ & $\begin{array}{c}46,4 \mathrm{c} \\
(48,27 \%)\end{array}$ & $\begin{array}{c}3,2 \mathrm{c} \\
(43,75 \%)\end{array}$ & $\begin{array}{c}100,8 \mathrm{~b} \\
(23,59 \%)\end{array}$ & $\begin{array}{c}51,2 \mathrm{c} \\
(19,74 \%)\end{array}$ & $\begin{array}{c}48,6 \mathrm{c} \\
(51,8 \%)\end{array}$ & $\begin{array}{c}40,6 \mathrm{c} \\
(34,92 \%)\end{array}$ \\
\hline 4 & P. $15 \%$ & $\begin{array}{c}64,8 \mathrm{~d} \\
(25,92 \%)\end{array}$ & $\begin{array}{c}45,8 \mathrm{~d} \\
(47,29 \%)\end{array}$ & $\begin{array}{c}51.2 \mathrm{~d} \\
(53,12 \%)\end{array}$ & $\begin{array}{c}4,6 \mathrm{~d} \\
(60,86 \%)\end{array}$ & $\begin{array}{c}71,2 \mathrm{c} \\
(40,86 \%)\end{array}$ & $\begin{array}{c}38,0 \mathrm{~d} \\
(40,43 \%)\end{array}$ & $\begin{array}{c}36,4 \mathrm{~d} \\
963,81 \%)\end{array}$ & $\begin{array}{c}32,4 \mathrm{~d} \\
(47,9 \%)\end{array}$ \\
\hline 5 & P. $20 \%$ & $\begin{array}{c}70,0 \mathrm{e} \\
(31,42 \%)\end{array}$ & $\begin{array}{c}51,2 \mathrm{e} \\
(53,12 \%)\end{array}$ & $\begin{array}{c}56,0 \mathrm{e} \\
(57,14 \%)\end{array}$ & $\begin{array}{c}5,4 \mathrm{e} \\
(66,66 \%)\end{array}$ & $\begin{array}{c}24.0 \mathrm{~d} \\
(80,06 \%)\end{array}$ & $\begin{array}{c}34,8 \mathrm{e} \\
(45,45 \%)\end{array}$ & $\begin{array}{c}24,0 \mathrm{e} \\
(76,14 \%)\end{array}$ & $\begin{array}{c}23,8 \\
(61,73 \%)\end{array}$ \\
\hline
\end{tabular}

Note: Numbers of which are followed by different letters in the same columns has a result of significantly different at the level of testing with Duncan'N 5\% $(0,05)$ 


\section{ACKNOWLEDGMENT}

1. To the Headmaster of Udayana University who had given us the chance to conduct this research until completion.

2. To the head of LPPM of Udayana University who had given me the chance to conduct this research through the budget listing of Budget conduction program of Udayana University.

3. To the team of research and university students who had been involved in this research.

\section{REFERENCES}

[1] Badan Pusat Statistik dan Direktorat Jendral Bumi dan Produksi. 2006. Produksi Tomat Menurut Provinsi Tahun 2002-2006. Available: http://www.bps.go.id//produksitomat/ [15 June 2013].
[2] Dropkin, VH. 1991. Pengantar Nematologi Tumbuhan Edisi 2. (Terjemahan). Yogyakarta: Gadjah Mada University Press.

[3] Adiputra, M. G. 2006. Pengantar Nematologi Tumbuhan. Jurusan Hama dan Penyakit Tumbuhan Fakultas Pertanian Universitas Udayana.

[4] Agrios, G.N. 1970. Plant Pathology. 2nd Printing. New York: Academic Press. 629 p.

[5] Sritamin, M., I N. Wijaya, dan I D.P. Singarsa. 2015. Efektifitas Berba-gai Konsentrasi Ekstrak Jenis Daun Tanaman Terhadap Populasi Nematoda Puru Akar, Meloidogyne spp. dan Hasil Tanaman Tomat. Laporan Hasil Penelitian Hibah Unggulan Udayana 2015

[6] Kerry, B.R. 2001. Exploitation of the nematophagus Fungal Verticullum chlamydosporum Godard of the Biological Control of Root-Knot Nematodes. 